\title{
Hubungan Efikasi Diri dengan Perilaku Mencontek
}

\author{
Devi Kusrieni \\ SMP N 2 Ampelgading Pemalang \\ Jl. Comal Baru Ampelgading, Pemalang, Indonesia. \\ Email: devikusrieni@rocketmail.com
}

\begin{abstract}
This study aims to determine the relationship between self-efficacy with cheating behavior in class X SMA Negeri 4 Yogyakarta in Academic Year 2014/2015. This research is a correlation. The population in this study were students of class X SMA Negeri 4 Yogyakarta in Academic Year 2014/2015. Subjects numbered 65 students out of a population of 260 students, making the subject of research carried out by random sampling technique. Instruments in this study using a questionnaire. The results of this study showed that self-efficacy against cheating behavior in class X SMA Negeri 4 Yogyakarta coined the roles of $21.3 \%$ and the remaining $78.7 \%$ of cheating behavior is caused by other variables outside of self-efficacy as procrastination, peer pressure, and pressure from parents. This study to conclude that there is a negative relationship between self-efficacy with cheating behavior in class X SMA Negeri 4 Yogyakarta academic year 2014/2015. Information from this research can serve as a basic reference program development guidance and counseling services to help students develop self-efficacy in minimizing the cheating behavior.
\end{abstract}

Keywords: self-efficacy, behavioral cheating

\begin{abstract}
Penelitian ini bertujuan untuk mengetahui hubungan antara efikasi diri dengan perilakumencontek pada siswa kelas X SMA Negeri 4 Yogyakarta Tahun Ajaran 2014/2015.Penelitian ini merupakan penelitian korelasi. Populasi dalam penelitian ini adalah siswa kelas X SMA Negeri 4 Yogyakarta Tahun Ajaran 2014/2015. Subjek penelitian berjumlah 65 siswa dari populasi sebanyak 260 siswa, pengambilan subjek penelitian dilakukan dengan teknik random sampling.Instrumen dalam penelitian ini menggunakan angket.Hasil penelitian inimenunjukkan bahwa efikasi diri terhadap perilaku mencontek pada siswa kelas X SMA Negeri 4 Yogyakarta memiiki peran sebesar 21,3\% dan sisanya 78,7\% perilaku mencontek disebabkan oleh variabel lain di luar efikasi diri seperti prokrastinasi, tekanan dari teman sebaya, dan tekanan dari orang tua.Penlitian ini disimpulkan bahwa ada hubungan negatif antara efikasi diri dengan perilaku mencontek pada siswa kelas X SMA Negeri 4 Yogyakarta tahun ajaran 2014/2015.Informasi dari hasil penelitian ini dapat dijadikan sebagai acuan dasar pengembangan program layanan bimbingan dan konseling untuk membantu siswa mengembangkan efikasi diri dalam meminimalisasikan perilaku mencontek.
\end{abstract}

Kata kunci:efikasi diri, perilaku mencontek

\section{Pendahuluan}

Pendidikan merupakan kebutuhan yang harus dipenuhi sepanjang hayat. Tanpa pendidikan siswa tidak dapat hidup berkembang sejalan dengan cita-cita untuk maju, sejahtera, dan bahagia. Pendidikan tidak hanya dipandang sebagai usaha pemberian informasi dan pembentukan keterampilan, tetapi mencakup usaha untuk mewujudkan keinginan, kebutuhan dan kemampuan siswa untuk mencapai pola hidup pribadi dan sosial yang memuaskan.

Pendidikan merupakan sarana untuk persiapan kehidupan yang akan datang, maupun kehidupan siswa yang sedang dialami. Sesuai dengan tujuan pendidikan Undang-Undang Sistem Pendidikan Nasional Nomor 20 Tahun 2003 pasal 3 menyatakan bahwa Pendidikan Nasional berfungsi mengembangkan kemampuan dan membentuk watak serta peradaban bangsa yang bermartabat dalam rangka mencerdaskan kehidupan bangsa, bertujuan untuk berkembangnya potensi peserta didik agar menjadi manusia yang beriman dan bertakwa kepada Tuhan Yang Maha Esa, berakhlak mulia, sehat, berilmu, cakap, kreatif, mandiri, dan menjadi warga negara yang demokratis serta bertanggung jawab.

Siswa merupakan unsur utama dalam pendidikan. Siswa sebagai individu sedang berada dalam proses berkembang atau menjadi (becoming), yaitu berkembang ke arah kematangan atau kemandirian. Siswa memerlukan bimbingan untuk mencapai kemandirian tersebut karena siswa masih kurang memiliki pemahaman 
atau wawasan tentang diri dan lingkungan, juga pengalaman dalam menentukan arah kehidupan.

Bimbingan dan konseling sebagai salah satu komponen pendidikan mempunyai posisi dan peran yang cukup penting dan strategis. Bimbingan dan konseling berperan untuk memberikan layanan kepada siswa agar dapat berkembang secara optimal melalui proses pembelajaran secara efektif. Seperti tertera di dalam peraturan Menteri Pendidikan Nasional Nomor 35 Tahun 2010 tentang Petunjuk Teknis Ketentuan Pelaksanaan Jabatan Fungsional dan Kreditnya yang berbunyibimbingan dan konseling merupakan komponen sekolah yang bertugas memberikan layanan dan bimbingan kepada siswa dalam upaya mengoptimalkan potensi siswa agar mampu mandiri dan berkembang secara optimal dalam bidang pribadi, belajar, sosial, dan karir.

Tugas utama seorang siswa adalah belajar, tetapi tidak semua siswa memiliki pengelolaan belajar yang baik, seperti pengelolaan waktu. Pengelolaan waktu belajar yang kurang baik menyebabkan siswa sering melakukan penundaan dalam mengerjakan tugas-tugas akademik. Siswa yang belum dapat mengelola waktu antara lain jadwal belajar yang tidak menentu atau menggunakan Sistem Kebut Semalam (SKS) dalam menghadapi ujian semester. Kebiasaankebiasaan belajar seperti Sistem Kebut Semalam (SKS) tentu tidak termasuk metode belajar yang baik.

Salah satu bentuk tindakan salahsuai yang sering terjadi pada siswa dalam proses pembelajaran adalah perilaku mencontek. Istilah mencontek bukan lagi menjadi kata asing dalam dunia pendidikan di Indonesia. Mencontek dapat ditemui pada siswa SD sampai SMA atau bahkan sampai perguruan tinggi. Cheating (mencontek) menurut Wikipedia Encyclopedia sebagai suatu tindakan tidak jujur yang dilakukan secara sadar untuk menciptakan keuntungan yang mengabaikan prinsip keadilan.

Perilaku mencontek telah dianggap sebagai tindakan yang biasa dilakukan oleh para pelajar. Mencontek dipandang sebagai salah satu usaha yang dilakukan siswa untuk memperoleh nilai yang bagus saat tes ataupun ujian. Perilaku mencontek yang dilakukan siswa saat ujian, dapat mengikis kepribadian positif di dalam diri siswa. Hal ini disebabkan perilaku mencontek merupakan tindakan curang yang tidak j ujur dan kurang usaha secara optimal seperti belajar tekun sebelum ujian.

Menurut hasil penelitian yang dilakukan seorang siswa SMA favorit di Surabaya terhadap teman sekolahnya dengan sampel $7 \%$ dari seluruh siswa (lebih dari 1400 siswa), menghasilkan data bahwa $80 \%$ dari sampel pernahmencontek (52 \% sering dan $28 \%$ jarang), sedangkan medium yang paling banyak digunakan sebagai sarana mencontek adalah teman $38 \%$ dan meja tulis $26 \%$. Uniknya ada 51 $\%$ dari siswa yang mencontek, ingin menghentikan kebiasaan buruknya tersebut (Widiawan, dalam Kushartanti, 2009).

Pada dasarnya perilaku mencontek dapat merugikan banyak pihak, yaitu siswa yang mencontek ataupun siswa yang dicontek. Siswa yang mencontek tidak dapat mengetahui seberapa besar kemampuan diri dalam memahami dan menguasai pelajaran yang didapat, sedangkan siswa yang dicontek secara tidak langsung haknya diambil oleh siswa yang mencontek. Selain itu perilaku mencontek dapat menyulitkan guru dalam mengukur tingkat keberhasilan dari proses belajar-mengajar di sekolah sebab nilai yang diperoleh siswa dengan hasil mencontek bukanlah nilai yang sesungguhnya yang menunjukan tingkat kemampuan dan pemahaman siswa itu sendiri.

Hasil observasi yang dilakukan peneliti pada tanggal 16 Agustus 2014 tehadap dua orang guru bimbingan dan konseling di SMA Negeri 4 Yogyakarta, diproleh hasi bahwa guru bimbingan dan konseling kurang berperan aktif dalam mencegah perilaku mencontek. Hal tersebut dapat dibuktikan dengan masih ada siswa yang melakukan tindakan mencontek saat ujian tengah semester. Khususnya pada siswa kelas X, siswa mencontek dengan cara meminta jawaban dari siswa sebelah dan ada juga siswa yang mencontek dengan menggunakan handphone yang di sembunyikan di dalam laci meja. Padahal ada guru yang mengawasi tetapi siswa tetap saja mencontek.

Hasil penelitian Kushartanti (2009) mengungkapkan bahwa 90\% siswa SMA N 1 Surakarta jarang mencontek, 3\% siswa sering mencontek, dan $7 \%$ siswa tidak pernah mencontek. Trik yang banyak digunakan siswa adalah dengan bertanya dengan teman 32\% dan melirik 25\%. Totalnya $100 \%$ dari siswa yang 
mencontek, ingin menghentikan kebiasaan tersebut. Dari hal tersebut dapat dilihat bahwa, masih ada siswa yang mencontek saat ujian yaitu dengan cara bertanya kepada teman dan melirik jawaban teman.

Faktor-faktor yang mempengaruhi siswa untuk mencontek yaitu pertama kurang kesiapan siswa dalam menghadapi ulangan atau ujian. Biasanya siswa yang tidak memiliki kesiapan dalam menghadapi ujian adalah siswa yang suka menunda-nunda belajar (prokrastinasi). Siswa yang menunda pekerjaan pada akhirnya memiliki pengetahuan yang rendah mengenai ujian yang dihadapi, akibatnya siswa memilih cara yang salah yaitu mencontek. Kedua, sikap siswa yang kurang percaya diri dan yakin pada jawaban sendiri. Siswa yang memiliki keyakinan diri rendah merupakan salah satu indikasi terjadinya perilaku mencontek karena siswa tersebut tidak dapat menyelesaikan tugasnya sendiri. Ketiga, adanya kesempatan atau peluang untuk mencontek dan bekerjasama. Ada tipe pengawas yang tidak peduli dengan apa yang dilakukan siswa pada saat ujian. Hal ini tentu saja langsung dimanfaatkan oleh siswa yang memang berniat untuk mencontek. Dampak negatif yang ditimbulkan dari mencontek yaitu seperti siswa menjadi malas belajar, siswa menjadi tidak jujur, menimbulkan sikap menghalalkan berbagai cara untuk mencapai tujuan dan hilang rasa percaya diri.

Berdasarkan hasil wawancara peneliti dengan seorang guru bimbingan dan konseling di SMA Negeri 4 Yogyakarta pada tanggal 5 September 2014, dapat diketahui bahwa siswa mencontek disebabkan karena efikasi diri siswa yang rendah dan kurang rasa percaya diri siswa dengan hasil pekerjaannya. Efikasi diri merupakan salah satu aspek pengetahuan tentang diri atau self knowledge yang paling berpengaruh dalam kehidupan manusia sehari-hari. Hal ini disebabkan efikasi diri yang dimiliki ikut mempengaruhi individu dalam menentukan tindakan yang akan dilakukan untuk mencapai suatu tujuan termasuk perkiraan berbagai kejadian yang akan dihadapi. Seperti yang diungkapkan oleh Myers dalam penelitian Jannah (2013) bahwa efikasi diri sangat berperan penting dalam diri siswa. Siswa dengan efikasi diri yang tinggi akan memperlihatkan sikap yang lebih gigih, tidak cemas dan tidak mengalami tekanan dalam menghadapi masalah.

Tingkat efikasi diri setiap siswa berbeda-beda antara siswa satu dengan yang lain. Perbedaan tersebut berdasarkan tiga dimensi efikasi diri yaitu pertama dimensi tingkat (level) yang berkaitan dengan tingkat kesulitan tugas ketika siswa merasa mampu untuk melakukan. Dimensi ini memiliki implikasi terhadap pemilihan tingkah laku yang akan dicoba atau dihindari. Siswa akan mencoba tingkah laku yang dirasa mampu dilakukan dan menghindari tingkah laku yang berada di luar batas kemampuan yang dirasakan. Kedua, dimensi kekuatan (strength) yaitu dimensi ini berkaitan dengan tingkat kekuatan dari keyakinan atau pengharapan siswa mengenai kemampuan. Keyakinan yang lemah mudah digoyahkan oleh pengalaman-pengalaman yang tidak mendukung. Sebaliknya, keyakinan yang mantap mendorong siswa tetap bertahan dalam usaha. Meskipun mungkin ditemukan pengalaman yang kurang menunjang. Ketiga, dimensi generalisasi yaitu dimensi yang berkaitan dengan luas bidang tingkah laku yang mana siswa merasa yakin akan kemampuan diri. Terbatas pada situasi tertentu atau pada serangkaian aktivitas dan situasi yang bervariasi.

Tujuan penelitian ini untuk mengetahui hubungan efikasi diri dengan perilaku mencontek pada siswa kelas X SMA Negeri 4 Yogyakarta. Efikasi diri siswa yang tinggi dipandang dapat menjadikan siswa tidak terlibat dalam perilaku mencontek. Oleh karena itu diharapkan perilaku mencontek dapat diminimalisasikan melalui pengembangan efikasi diri siswa. Informasi dari hasil penelitian ini dapat dijadikan sebagai acuan dasar pengembangan program layanan bimbingan dan konseling untuk membantu siswa mengembangkan efikasi diri dalam meminimalisasikan perilaku mencontek.

\section{Kajian Literatur}

\section{Perilaku Mencontek}

Perilaku mencontek merupakan perilaku negatif yang biasa dilakukan oleh siswa saat ujian. Perilaku mencontek telah dianggap sebagai tindakan yang wajar. Padahal perilaku mencontek dapat berdampak buruk bagi siswa. Mencontek secara sederhana dapat dimaknai sebagai penipuan atau melakukan perbuatan tidak jujur. 
Mencontek juga dapat dimaknai sebagai perilaku ketidakjujuran akademik. Menurut Sari dkk (2013) perilaku mencontek merupakan tindakan curang yang mengabaikan kejujuran, mengabaikan usaha optimal seperti belajar tekun sebelum ujian, serta mengikis kepercayaan diri siswa. Dellington (Intan Irawati, 2008, Hartanto, 2012: 10) berpendapat mencontek berarti upaya yang dilakukan seseorang untuk mendapatkan keberhasilan dengan cara- cara yang tidak fair (tidak jujur).

Definisi lain tentang mencontek menurut Pincus dan Schmelkin (dalam Leda Nath dan Micahel Lovaglia, 2009; Hartanto, 2012) menyatakan bahwa perilaku mencontek dilakukan dengan cara membuat catatan, melihat pekerjaan teman yang lain (mencuri), atau membuat catatan atau istilah dalam suatu kertas. Pendapat lain dikemukakan oleh Tamekia Reece, 2009 sebagaimana dikutip oleh Hartanto (2012: 12) bahwamencontek meliputi kegiatan atau meniru atau melihat jawaban siswa lain, melihat sebagian atau keseluruhan pekerjaan siswa lain dan mengakuinya sebagai hasil dari pekerjaannya, melihat jawaban dari internet (ketika hal tersebut dilarang atau tidak di ijinkan, menyimpan jawaban pada telepon seluler (handphone) atau MP3 Player, menggunakan catatan (kepekan), serta meminjam dan melihat naskah hasil pekerjaan teman. Menurut Hamdani (2014: 3) mencontek adalah melakukan kegiatan yang bertujuan untuk mencari jawaban soal-soal ujian yang dilakukan dengan cara-cara tertentu sehingga tidak diketahui oleh siswa lain.

Mencontek adalah perilaku ketidakjujuran akademik yang dilakukan seseorang untuk mendapatkan keberhasilan dengan cara-cara yang tidak jujur yaitu dengan cara membuat catatan atau melihat lembar jawaban teman yang lain.

Menurut Hetherington and Feldman,1964 sebagaimana dikutip oleh Hartanto (2012:17) mengelompokkan mencontek menjadi empat bentuk yaitu: 1) individualistic-opportunistic yaitu perilaku siswa mengganti suatu jawaban ketika ujian atau tes sedang berlangsung dengan menggunakan catatan ketika guru keluar dari kelas; 2) individualistic-planned yaitu siswa menggunakan catatan ketika tes atau ujian berlangsung, atau membawa jawaban yang telah lengkap atau dipersiapkan dengan menulis terlebih dahulu sebelum berlangsung ujian; 3) social-active yaitu perilaku mencontek siswa dengan mengcopi atau melihat atau meminta jawaban dari siswa lain; 4) social-pasif yaitu perilaku mencontek siswa dengan mengizinkan seseorang melihat atau mengcopi jawaban.Berdasarkan uraian di atas dapat disimpulkan bahwa bentuk-bentuk perilaku mencontek yang biasa dilakukan siswa dibagi menjadi empat yaitu individualistic-opportunistic, individualistic-planned, social-active, dan socialpasif.

Menurut Hamdani (2014: 63) mencontek memiliki dampak negatif antara lain:

1. Bersifat manipulatif atau tidak jujur, mencontek merupakan salah satu tindakan atau aksi yang memanipulasi/ menipu siswa lain bahkan diri sendiri. Ujian dilakukan untuk mengetahui hasil dari kegiatan belajar. Hasil belajar tersebut merupakan cerminan sebenarnya dari kemampuan yang siswa miliki. Jika siswa mencontek maka bayangan yang sesungguhnya tidak akan terlihat. Siswa tidak akan mengetahui kemampuan atau potensi yang dimiliki.

2. Tidak percaya dengan kemampuan sendiri, siswa yang mencontek tidak percaya pada kemampuan diri sendiri. Pada umumnya siswa yang termasuk dalam kategori ini memiliki pikiran negatif pada diri sendiri tapi siswa selalu menginginkan hasil yang sangat baik. Oleh karena itu, siswa lebih memilih untuk melakukan mencontek.

3. Menumbuhkan sifat melanggar atau curang, mencontek merupakan salah satu perbuatan yang tidak boleh dilakukan tapi dengan keadaan sadar siswa justru mencontek. Jika hal tersebut tidak segera dihentikan maka kemungkinan besar siswa akan merasa bahwa melanggar peraturan merupakan hal yang wajar. Tentu saja hal ini memiliki dampak yang tidak baik bagi diri sendiri maupun siswa lain.

4. Termasuk perbuatan yang dapat mempengaruhi siswa lain, kebiasaan mencontek dapat mempengaruhi dari siswa satu ke siswa lain. Apalagi jika siswa yang sudah terbiasa mengerjakan soal-soal ujian secara bersama-sama.

5. Mencontekmenjadikan kebiasaan, mencontek sering dilakukan karena terbukti mampu memberikan hasil yang diinginkan. Jika 
sudah merasa manfaat mencontek pada satu pelajaran maka tidak menutup kemungkinan mencontek yang siswa lakukan akan berlanjut di pelajaran lain. Ketika siswa sudah terbiasa mencontek maka akan semakin sulit bagi siswa untuk menghentikan kebiasaan tersebut. Bahkan mencontek akandilakukan hingga pendidikan yang lebih tinggi.

6. Malas lawan cerdas, ada yang mengatakan mencontek merupakan salah satu perbuatan cerdas untuk mendapatkan nilai yang bagus. Hal tersebut merupakan pendapat yang salah karena cerdas itu adalah mengerjakan sesuatu dengan efektif dan efisien tapi cerdas tidak dilakukan untuk melanggar peraturan sedangkan mencontek sudah jelas termasuk dalam golongan yang melanggar aturan.

7. Nilai lawan kemampuan, nilai merupakan penilaian berbentuk angka yang didapatkan setelah siswa mengikuti sebuah tes atau ujian. Dengan kata lain, nilai merupakan media yang digunakan untuk mengukur atau menunjukkan kemampuan yang ada pada siswa. Hanya saja, nilai yang siswa dapatkan menjadi tidak bermakna jika dalam proses penyelesaian soal ujian dilakukan dengan mencontek.

Berdasarkan uraian di atas dapat disimpulkan bahwa mencontek memiliki dampak negatif yaitu menjadikan siswa memiliki sifat manipulatif atau tidak jujur, tidak percaya dengan kemampuan sendiri, menumbuhkan sifat melanggar atau curang, mencontek termasuk perbuatan yang dapat mempengaruhi siswa lain, mencontek menjadikan kebiasaan, malas lawan cerdas, dan nilai lawan kemampuan.Menurut Bushway \& Nash, 1997; Schab, 1991; Whitlay, 1998; Whitley \& Keith-Spiegel, 2002; Kristin Voelkl Finn, 2004 sebagaimana dikutip oleh Hartanto (2012: 37) penyebab individu mencontek adalah: 1) ada tekanan untuk mendapatkan nilai yang tinggi, pada dasarnya setiap siswa memiliki keinginan yang sama, yaitu untuk mendapatkan nilai yang baik (tinggi). Keinginan tersebut terkadang membuat siswa menghalalkan segala cara, termasuk dengan mencontek; 2) keinginan untuk menghindari kegagalan, ketakutan mendapatkan kegagalan di sekolah merupakan hal yang muncul ke dalam bentuk (takut tidak naik kelas, takut mengikuti ulangan susulan) hal tersebut menyebabkan terjadi perilaku mencontek; 3) ada persepsi bahwa sekolah melakukan hal yang tidak adil, sekolah dianggap hanya memberikan akses ke siswa-siswi yang memiliki kemampuan menengah merasa tidak diperhatikan dan dilayani dengan baik; 4) kurang waktu untuk menyelesaikan tugas sekolah, siswa terkadang mendapatkan tugas secara bersamaan. Waktu penyerahan tugas yang bersamaan tersebut membuat siswa tidak dapat membagi waktu; 5) tidak ada sikap yang menentang perilaku mencontek di sekolah, perilaku mencontek di sekolah kadang-kadang dianggap sebagai permasalahan yang biasa, baik oleh siswa maupun oleh guru karena itu, banyak siswa yang membiarkan perilaku mencontek atau terkadang justru membantu terjadi perilaku mencontek.

Hamdani (2014: 76) juga berpendapat alasan siswa mencontek antara lain: 1) tidak mengerti dengan pelajaran yang disampaikan, jika seorang siswa mampu dan paham terhadap materi yang disampaikan maka siswa tersebut harus dapat menyelesaikan seluruh soal ujian dengan kemampuan yang dimiliki. Tapi, hal tersebut akan menjadi berbeda jika siswa tersebut tidak dapat menangkap pelajaran dengan baik. Berbagai cara akan dilakukan hanya untuk mendapatkan jawaban termasuk mencontek; 2) malas, malas merupakan masalah dasar dari seorang siswa mencontek. Banyak siswa yang memiliki kemampuan di atas rata-rata dan mampu mengikuti proses belajar dengan baik. Tapi, tidak menutup kemungkinan jika siswa tersebut masih terlibat mencontek. Salah satu faktor penyebab adalah ketidaktertarikan siswa terhadap materi pelajaran yang disampaikan maka rasa malas yang sebenarnya tidak terlalu besar akan makin berkembang. Pada akhirnya siswa tidak berminat untuk mengikuti pelajaran dan saat ujian siswa mencontek; 3) orientasi pada nilai bukan ilmu, jika sejak awal siswa lebih mengutamakan nilai daripada ilmu maka sama saja dengan mengedepankan hasil tanpa didasari proses yang baik. Mencontek dikenal sebagai langkah yang praktis yang dapat menghasilkan nilai yang maksimal tanpa harus belajar dengan tekun; 4) ajakan teman, lingkungan sekitar pasti memberi dampak terhadap tindakan yang di ambil. Termasuk teman-teman yang ada di dalam kelas. Tidak jarang siswa yang dari awal bukan termasuk siswa mencontek beralih menjadi 
mencontek. Hal tersebut karena alasan solidaritas, saling berbagi, kasihan, diancam teman.

Penyebab perilaku mencontek menurut Hartanto (2012:44) dapat dikelompokkan menjadi dua bagian besar, yaitu 1) faktor internal dan 2) faktor eksternal. Faktor internal dalam perilaku mencontek adalah kurang pengetahuan dan pemahaman tentang apa yang dimaksud dengan mencontek atau plagiarism, self-efficacy yang rendah, dan status ekonomi sosial. Faktor internal lain adalah keinginan untuk mendapatkan nilai yang tinggi, nilai moral (personal values) yaitu siswa menganggap perilaku mencontek sebagai perilaku yang wajar, kemampuan akademik yang rendah, time management, prokrastinasi. Faktor eksternal terjadi perilaku mencontek adalah tekanan dari teman sebaya, tekanan dari siswa tua, peraturan sekolah yang kurang jelas, dan sikap guru yang tidak tegas terhadap perilaku mencontek.

Berdasarkan uraian di atas dapat disimpulkan bahwa penyebab siswa mencontek berasal dari faktor internal dan eksternal. Salah satu penyebab siswa mencontek dari faktor internal adalah efikasi diri siswa yang masih rendah. Siswa yang memiliki efikasi rendah merupakan indikasi lain bagi perilaku mencontek.

\section{Peran Bimbingan dan Konseling}

Guru bimbingan dan konseling di sekolah sangat berperan dalam memberikan layanan kepada siswa. Layanan bimbingan dan konseling bertujuan untuk membantu siswa mengatasi kesulitan yang berkaitan dengan pelaksanaan tugas-tugas perkembangan. Salah satu peran bimbingan dan konseling yaitu untuk mencegah perilaku mencontek. Bimbingan dan konseling merupakan terjemahan dari istilah "guidance" dan "counseling” dalam bahasa inggris. Secara harfiyah istilah "guidance" berasal dari kata "guide" yang memiliki arti: mengarahkan (to direct), memandu (to pilot), mengelola (to manage), dan menyetir (to steer). Menurut Yusuf (2009:39) bimbingan dapat diartikan sebagai proses pemberian bantuan (process for helping) konselor kepada individu (konseli) secara berkesinambungan agar mampu memahami potensi diri dan lingkungan, menerima diri, mengembangkan diri secara optimal, dan meyesuaikan diri secara positif dan konstruktif terhadap tuntutan norma kehidupan (agama dan budaya) sehingga mencapai kehidupan yang bermakna (berbahagia), baik secara personal maupun sosial.

Menurut Suherman (2007: 10) bimbingan merupakan proses bantuan kepada individu (konseli) sebagai bagian dari program pendidikan yang dilakukan oleh tenaga ahli (konselor) agar individu (konseli) mampu memahami dan mengembangkan potensi secara optimal sesuai dengan tuntutan lingkungan. Sedangkan konseling merupakan proses helping atau bantuan dari konselor (helper) kepada konseli, baik melalui tatap muka maupun media (cetak maupun elekronik, internet atau telepon), agar klien dapat mengembangkan potensi diri atau memecahkan masalah, sehingga berkembang menjadi seorang pribadi yang bermakna, baik bagi diri sendiri, maupun siswa lain, dalam rangka mencapai kebahagiaan bersama. Menurut Prayitno dan Erman (2013: 105) konseling adalah proses pemberian bantuan yang dilakukan melalui wawancara konseling oleh seorang ahli (konselor) kepada individu yang sedang mengalami sesuatu masalah (konseli) yang bermuara pada teratasi masalah yang dihadapi oleh klien.Dari penjelasan tersebut maka dapat disimpulkan bahwa pengertian bimbingan dan konseling adalah proses pemberian bantuan dari konselor kepada konseli secara berkesinambungan, baik langsung tatap muka dengan wawancara maupun tidak langsung melalui media yang bertujuan agar konseli dapat memahami dan mengembangkan potensi diri maupun lingkungan dan mampu memecahkan masalah yang dialaminya.

Menurut Prayitno dan Erman (2013:114) tujuan umum bimbingan dan konseling untuk membantu konseli memperkembangkan diri secara optimal sesuai dengan tahap perkembangan dan predisposisi yang dimiliki (seperti kemampuan dasar dan bakat-bakat), berbagai latar belakang yang ada (seperti latar belakang keluarga, pendidikan, status sosial ekonomi), serta sesuai dengan tuntutan positif lingkungan.Sedangkan menurut Yusuf (2009:49) secara khusus bimbingan dan konseling bertujuan untuk membantu siswa atau peserta didik agar dapat mencapai tugas-tugas perkembangan yang meliputi aspek pribadi-sosial, belajar (akademik), dan karir.Sutirna (2013: 18) berpendapat tujuan pelayanan bimbingan dan konseling ialah agar konseli (peserta didik) dapat: merencanakan 
kegiatan penyelesaian studi, perkembangan karir serta kehidupan di masa yang akan datang, mengembangkan seluruh potensi dan kekuatan yang dimiliki seoptimal mungkin, menyesuaikan diri dengan lingkungan (pendidikan, lingkungan masyarakat serta lingkungan kerja), mengatasi hambatan dan kesulitan yang dihadapi dalam studi (penyesuaian dengan lingkungan pendidikan masyarakat maupun lingkungan kerja).

Layanan bimbingan dan konseling disekolah bertujuan membantu siswa mengatasi kesulitan yang berkaitan dengan pelaksanaan tugas-tugas perkembangan, baik perkembangan pendidikan, pekerjaan maupun pribadi. Tujuan bimbingan dan konseling terkait dengan penelitian ini yaitu guru bimbingan dan konseling memberikan layanan preventif terhadap perilaku mencontek.Menurut Yusuf (2009:51) bimbingan dan konseling dapat diklasifikasikan menjadi empat bidang yaitu bidang akademik (belajar), bidang pribadi,bidang sosial dan bidang karir.Bimbingan dan konseling akademik adalah proses bantuan untuk memfasilitasi siswa dalam mengembangkan pemahaman dan keterampilan dalam belajar, dan memecahkan masalah-masalah belajar atau akademik. bimbingan dan konseling akademik menyangkut pengenalan kurikulum, pengembangan sikap dan kebiasaan belajar yang positif, pengembangan motif berprestasi, cara belajar yang efektif, penyelesaian tugas-tugas dan latihan, pengembangan kesadaran belajar sepanjang hayat, pencarian dan penggunaan sumber belajar, penyesuaian diri terhadap semua tuntutan program pendidikan sehingga dapat tujuan akademik yang diharapkan, perencanaan pendidikan lanjutan dan cara mengatasi kesulitan belajar. Bimbingan dan konseling pribadi merupakan proses bantuan untuk memfasilitasi siswa agar memiliki pemahaman tentang karakteristik diri, kemampuan mengembangkan potensi diri, dan memecahkan masalah-masalah yang dialami. Bimbingan dan konseling pribadi menyangkut pengembangan: komitmen hidup beragama, pemahaman sifat dan kemampuan diri dan kemampuan mengatasi masalah-masalah pribadi (stress, frustasi, dan konflik pribadi). Bimbingan dan konseling sosial adalah proses bantuan untuk memfasilitasi siswa agar mampu mengembangkan pemahaman dan keterampilan berinteraksi sosial atau hubungan insani (human relationship) dan memecahkan masalah-masalah sosial yang dialami. Bimbingan sosial, menyangkut pengembangan: pemahaman tentang keragaman budaya atau adat istiadat, sikap-sikap sosial (sikap empati, altruis, toleransi, dan kooperasi), dan kemampuan berhubungan sosial secara positif dengan siswa tua, guru, teman, dan staf sekolah.Bimbingan karir yaitu proses bantuan untuk memfasilitasi siswa dalam perencanaan, pengembangan dan pemecahan masalah-masalah karir, seperti: pemahaman terhadap jabatan dan tugas-tugas kerja, pemahaman kondisi dan kemampuan diri, pemahaman kondisi lingkungan, perencanaaan dan pengembangan karir, penyesuaian pekerjaan, dan pemecahan masalahmasalah karir yang dihadapi.

Berdasarkan bidang-bidang bimbingan dan konseling diatas dapat disimpulkan bahwa peran bimbingan dan konseling mencangkup dalam empat bidang yaitu bidang akademik, pribadi, sosial dan karir. Pada penelitian ini termasuk dalam bidang bimbingan dan konseling akademik (belajar), karena perilaku mencontek merupakan hasil dari belajar yang kurang efektif.

Menurut Yusuf dan Juntika Nurihsan (2010:16) fungsi bimbingan dan konseling dapat dikelompokkan menjadi tujuh yaitu fungsi pemahaman, fungsi preventif, fungsi pengembangan, fungsi perbaikan (penyembuhan), fungsi penyaluran, fungsi adaptasi dan fungsi penyesuaian. Fungsi bimbingan dan konseling terkait dengan penelitian ini lebih mengarahkan kepada fungsi preventif yaitu upaya konselor untuk senantiasa mengantisipasi agar siswa tidak mencontek saat ujian.

\section{Efikasi Diri}

Efikasi diri merupakan salah satu aspek pengetahuan tentang diri atau self-knowledge yang paling berpengaruh dalam kehidupan manusia sehari-hari. Hal ini disebabkan efikasi diri yang dimiliki ikut mempengaruhi individu dalam menentukan tindakan yang akan dilakukan untuk mencapai suatu tujuan, termasuk didalam perkiraan berbagai kejadian yang akan dihadapi. Menurut Baron dan Byrne, 1991 sebagaimana dikutip oleh Ghufron dan Rini (2010:73) efikasi diri sebagai evaluasi seseorang mengenai kemampuan atau kompetensi diri untuk melakukan suatu tugas, mencapai tujuan, dan mengatasi hambatan. Komalasari, dkk (2011:150) berpendapat efikasi diri adalah penilaian diri, 
apakah individu memiliki keyakinan bahwa individu mampu atau tidak mampu melakukan tindakan dengan baik dan memuaskan sesuai yang dipersyaratkan.

Alwisol (2009:287) menyatakan bahwa efikasi diri sebagai persepsi diri sendiri mengenai seberapa bagus diri dapat berfungsi dalam situasi tertentu, efikasi diri berhubungan dengan keyakinan bahwa diri memiliki kemampuan melakukan tindakan yang diharapkan.Efikasi diri adalah pertimbangan seseorang akan kemampuan untuk mengorganisasikan dan menampilkan tindakan yang diperlukan dalam mencapai tujuan yang diinginkan, tidak tergantung pada jenis keterampilan dan keahlian tetapi lebih berhubungan dengan keyakinan tentang apa yang dapat dilakukan dengan berbekal keterampilan dan keahlian. Menurut Feist, J \& G, J, Feist (2010: 212) manusia yang yakin bahwa dapat melakukan sesuatu yang mempunyai potensi untuk dapat mengubah kejadian di lingkungan, akan lebih mungkin bertindak dan lebih mungkin untuk menjadi sukses daripada manusia yang mempunyai efikasi diri yang rendah.

Bandura (dalam Widaryati, 2013) mengemukakan bahwa individu yang mempunyai efikasi diri yang rendah cenderung menyerah ketika dihadapkan pada suatu permasalahan. Selain itu is akan menetapkan target yang lebih rendah dan keyakinan terhadap pencapaian target juga rendah sehingga usaha yang dilakukan lemah, cenderung menghindar bila ada tugas. Dengan demikian, lemahnya efikasi diri dapat membuat siswa enggan melakukan kewajibannya sebagai siswa, yaitu belajar dengan baik. Siswa enggan bersaing mengejar prestasi. Padahal saat ini persaingan semakin ketat, dibutuhkan generasi muda yang unggul. Keunggulan tersebut dapat diperoleh melalui proses belajar yang optimal. Proses belajar yang optimal dapat diraih apabila efikasi diri yang dimiliki siswa cukup.

Lebi lanjut, menurut Bandura (dalam Widaryati, 2013) faktor yang dapat mempengaruhi efikasi diri, yaitu mastery experience (pengalaman menyelesaiakan masalah), pengalaman orang lain sebagai model (Vicarious experience), persuasi verbal (verbal persuasion), dan keadaan fisiologis dan emosional individu (emotional arousal). Pajares \& Schunk (dalam Widaryati, 2013) mengemukakan bahwa keluarga, sekolah dan teman sebaya dapat membentuk efikasi diri individu. Berdasar hal-hal tersebut, peneliti mencari bentuk kegiatan yang dapat mempengaruhi efikasi diri. Dengan adanya kegiatan tersebut diharapkan dapat membentuk dan meningkatkan efikasi diri (keyakinan diri) individu agar dapat mengubah persepsi ketidakmampuan terhadap diri sendiri menjadi yakin dan mampu untuk mengorganisasikan dan mengambil tindakan yang dibutuhkan sehingga akhirnya dapat membentuk perilaku yang relevan dan memperoleh hasil seperti yang diharapkan (Widaryati, 2013).

Berdasarkan beberapa pengertian di atas, dapat disimpulkan bahwa efikasi diri merupakan keyakinan, evaluasi maupun penilaian diri siswa terhadap kemampuan diri dalam melakukan tugas atau tindakan yang diperlukan untuk mencapai hasil tertentu maupun dalam mengatasi hambatan.

Menurut Bandura (dalam Ghufron dan Rini, 2010: 80) efikasi diri pada diri tiap siswa akan berbeda antara siswa satu dengan yang lain berdasarkan tiga dimensi. Tiga dimensi tersebut yaitudimensi tingkat (level), dimensi kekuatan (strength), dan dimensi generalisasi (generality). Dimensi tingkat (level)berkaitan dengan derajat kesulitan tugas ketika siswa merasa mampu untuk melakukan. Apabila siswa dihadapkan pada tugas-tugas yang disusun menurut tingkat kesulitan, maka efikasi diri siswa mungkin akan terbatas pada tugas-tugas yang mudah, sedang, atau bahkan meliputi tugas-tugas yang paling sulit, sesuai dengan batas kemampuan yang dirasakan untuk memenuhi tuntutan perilaku yang dibutuhkan pada masing-masing tingkat. Dimensi ini memiliki implikasi terhadap pemilihan tingkah laku yang akan dicoba atau dihindari. Siswa akan mencoba tingkah laku yang dirasa mampu dilakukan dan menghindari tingkah laku yang berada di luar batas kemampuan yang dirasakan.

Deskripsi dimensi selanjutnya adalah dimensi kekuatan (strength) berkaitan dengan tingkat kekuatan dari keyakinan atau pengharapan siswa mengenai kemampuan. Keyakinan yang lemah mudah digoyahkan oleh pengalaman-pengalaman yang tidak mendukung. Sebaliknya, keyakinan yang mantap mendorong siswatetap bertahan dalam usaha. Meskipun mungkin ditemukan pengalaman yang kurang menunjang. Dimensi ini biasa berkaitan langsung dengan dimensi level, yaitu makin tinggi taraf kesulitan tugas, makin 
lemah keyakinan yang dirasakan untuk menyelesaikan. Dimensi generalisasi (generality) berkaitan dengan luas bidang tingkah laku yang mana siswa merasa yakin akan kemampuan diri. Apakah terbatas pada situasi tertentu atau pada serangkaian aktivitas dan situasi yang bervariasi. Berdasarkan uraian di atas, dapat disimpulkan bahwa dimensi-dimensi efikasi diri adalah dimensi tingkat (level), dimensi kekuatan (strength), dan dimensi generalisasi (generality).

Menurut Bandura efikasi diri dapat ditumbuhkan dan dipelajari melalui empat sumber informasi utama yaitu pengalaman keberhasilan (mastery experience), pengalaman siswa lain (vicarious experience), persuasi verbal (verbal persuasion), dan kondisi fisilogis (physiological state). Pengalaman keberhasilan (mastery experience) memberikan pengaruh besar pada efikasi diri siswa karena didasarkan pada pengalaman-pengalaman pribadi siswa secara nyata yang berupa keberhasilan dan kegagalan. Pengalaman keberhasilan akan menaikkan efikasi diri siswa, sedangkan pengalaman kegagalan akan menurunkan. Setelah efikasi diri yang kuat berkembang melalui serangkaian keberhasilan, dampak negatif dari kegagalan-kegagalan yang umum akan terkurangi. Bahkan, kemudian kegagalan diatasi dengan usaha-usaha tertentu yang dapat memperkuat motivasi diri apabila seseorang menemukan lewat pengalaman bahwa hambatan tersulit pun dapat diatasi melalui usaha yang terus-menerus.

Deskripsi dari sumber informasi utama lainnya adalah pengalaman siswa lain (vicarious experience), yaitu bagaimana pengamatan terhadap keberhasilan siswa lain dengan kemampuan yang sebanding dalam mengerjakan suatu tugas akan meningkatkan efikasi diri siswa dalam mengerjakan tugas yang sama. Begitu pula sebaliknya, pengamatan terhadap kegagalan siswa lain akan menurunkan penilaian siswa mengenai kemampuan dan siswa akan mengurangi usaha yang dilakukan. Pada persuasi verbal (verbal persuasion), siswa diarahkan dengan saran, nasihat dan bimbingan sehingga dapat meningkatkan keyakinan tentang kemampuankemampuan yang dimiliki yang dapat membantu mencapai tujuan yang diinginkan. Siswa yang diyakinkan secara verbal cenderung akan berusaha lebih keras untuk mencapai suatu keberhasilan. Menurut Bandura (1997), pengaruh persuasi verbal tidaklah terlalu besar karena tidak memberikan suatu pengalaman yang dapat langsung dialami atau diamati siswa. Dalam kondisi yang menekan dan kegagalan terusmenerus, pengaruh sugesti akan cepat lenyap jika mengalami pengalaman yang tidak menyenangkan. Kondisi fisiologis (physiological state) yaitu siswa akan mendasarkan informasi mengenai kondisi fisiologis siswa untuk menilai kemampuan. Ketegangan fisik dalam situasi yang menekan dipandang siswa sebagai suatu tanda ketidakmampuan karena hal itu dapat melemahkan performansi kerja siswa.

Menurut Nelson-Jones (2011: 438) siswa dengan efikasi diri tinggi melihat bahwa penghalang dapat diatasi dengan terus berusaha dan dengan meningkatkan keterampilan manajemen-dirinya. Siswa dengan efikasi diri rendah akan berhenti berusaha saat menghadapi rintangan. Bandura, 1977 secara rinci fungsi efikasi antara lain pemilihan perilaku, besar usaha dan ketekunan, cara berfikir dan reaksi emosional. Pemilihan perilakumerupakan faktor yang sangat penting sebagai sumber pembentukan efikasi diri siswa karena hal ini berdasarkan kepada kenyataan keberhasilan siswa dapat menjalankan suatu tugas atau ketrampilan tertentu akan meningkatkan efikasi diri dan kegagalan yang berulang akan mengurangi efikasi diri.Besar usaha dan ketekunan yaitu keyakinan yang kuat tentang efektifitas kemampuan siswa akan sangat menentukan usaha untuk mencoba mengatasi situasi yang sulit. Pertimbangan efikasi juga menentukan seberapa besar usaha yang akan dilakukan dan seberapa lama bertahan dalam menghadapi tantangan. Semakin kuat efikasi diri maka semakin lama bertahan dalam usaha. Cara berfikir dan reaksi emosional yaitu dalam pemecahan masalah yang sulit, siswa yang mempunyai efikasi tinggi cenderung mengatribusikan kegagalan pada usaha-usaha yang kurang, sedangkan siswa yang mempunyai efikasi rendah menganggap kegagalan berasal dari kurangnya kemampuan siswa.

\section{Metode Penelitian}

Jenis penelitian yang digunakan dalam penelitian ini adalah penelitian korelasi, penelitian korelasi merupakan penelitian yang bertujuan untuk menemukan ada tidak hubungan 
yang diteliti, jika ada hubungan maka seberapa erat hubungan tersebut dan berarti atau tidak hubungan itu.Instrument penelitian yang digunakan dalam pnelitian ini berupa angket.Penelitian ini merupakan jenis penelitian dengan metode korelasi.Variabel dalam penelitian ini yaitu variabel efikasi diri dan variabel perilaku mencontek. Populasi dalam penelitian ini adalah siswa kelas X SMA Negeri 4 Yogyakarta Tahun Ajaran 2014/2015. Subjek penelitian berjumlah 65 siswa dari populasi sebanyak 260 siswa, dengan teknik pengambilan subjek penelitian engan cararandom sampling. Analisis data dalam penelitian ini menggunakan rumus product moment untuk uji validitas, dan menggunakan rumus alpha cronbach untuk uji Reliabilitas.

\section{Hasil Penelitian dan Pembahasan}

Penelitian ini dilaksanakan pada tanggal 24 September 2014 yang bertempat di SMA Negeri 4 Yogyakarta. Dalam penelitian ini, peneliti menggunakan angket sebagai instrumen untuk memperoleh data. Penelitian dilakukan hanya satu kali artinya peneliti tidak memberikan tindakan selanjutnya dalam penelitian. Pengambilan data dilaksanakan pada siswa kelas X SMA Negeri 4 Yogyakarta dengan jumlah 65 siswa dan semua tercatat sebagai administratif aktif dalam tahun berjalan pada sekolah yang bersangkutan.

Skor angket variabel efikasi diri dan perilaku mencontek dianalisis menggunakan bantuan komputer program SPSS (statistical package for social sciens) versi 16.0. Berdasarkan hasil analisis diperoleh deskripsi data variabel efikasi diri dan perilaku mencontek. Deskripsi tersebut dapat dilihat pada Tabel 1. Pada Tabel 1 dapat diketahui bahwa semakin tinggi efikasi diri, maka semakin rendah perilaku mencontek siswa. Sebaliknya semakin rendah efikasi diri siswa, maka semakin tinggi perilaku mencontek siswa. Adapun penggolongan variabel efikasi diri dibedakan menjadi tiga kategori yaitu tinggi, sedang, dan rendah. Klasifikasi penggolongan dapat dilihat pada Tabel 2, sedangkan penggolongan variabel perilaku dapat dilihat pada Tabel 3 yang dibedakan pula menjadi tiga kategori yaitu tinggi, sedang dan rendah
Tabel 1

Deskripsi Data Efikasi Diri dengan Perilaku Mencontek

\begin{tabular}{llccccc}
\hline No & Variabel & $\mathrm{N}$ & $\begin{array}{l}\text { Skor } \\
\text { Min }\end{array}$ & $\begin{array}{l}\text { Skor } \\
\text { Max }\end{array}$ & Mean & SD \\
\hline 1. & Efikasi diri & 65 & 84 & 151 & $\begin{array}{l}123,3 \\
0\end{array}$ & 14,30 \\
2. & $\begin{array}{l}\text { Perilaku } \\
\text { mencontek }\end{array}$ & 65 & 46 & 120 & 83,14 & 18,65 \\
\hline
\end{tabular}

Tabel 2

Distribusi Frekuensi Efikasi Diri

\begin{tabular}{cccc}
\hline Kategori & Interval & F & Prosentase \\
\hline Tinggi & $137,61-151$ & 9 & $13,8 \%$ \\
Sedang & $109,01-137,60$ & 47 & $72,3 \%$ \\
Rendah & $84-109,00$ & 9 & $13,8 \%$ \\
& Total & 65 & $100 \%$ \\
\hline
\end{tabular}

Tabel 3

Distribusi Frekuensi Perilaku Mencontek

\begin{tabular}{cccc}
\hline Kategori & Interval & F & Prosentase \\
\hline Tinggi & $101,79-120$ & 8 & $12,3 \%$ \\
Sedang & $64,49-101,78$ & 44 & $67,7 \%$ \\
Rendah & $46-64,48$ & 13 & $20,0 \%$ \\
& Total & 65 & $100 \%$ \\
\hline
\end{tabular}

Uji normalitas sebaran digunakan untuk mengetahui apakah populasi data berdistribusi normal atau tidak. Uji ini biasanya digunakan untuk mengukur data berskala ordinal, interval, ataupun rasio. Jika analisis menggunakan metode parametrik, maka persyaratan normalitas harus terpenuhi yaitu data berasal dari distribusi yang normal. Kaidah signifikasi yang digunakan adalah p > 0,05 maka sebaran skor subyek pada populasi (sebarannya dikatakan normal) dan sebaliknya apabila $\mathrm{p}<0,05$ maka sebarannya dikatakan tidak normal. Hasil uji normalitas untuk variabel efikasi diri dan perilaku mencontek dapat dilihat pada Tabel 4. Data pada tabel 4 diketahui bahwa skor variabel efikasi diri dan perilaku mencontek mempunyai sebaran normal. Semakin tinggi nlai $p$ maka skor variabel berada pada sebaran normal. 
EFIKASI DIRI, PERILAKU MENYONTEK

Tabel 4

Hasil Uji Normalitas Sebaran

\begin{tabular}{cccc}
\hline Variabel & $\chi^{2}$ & $P$ & Ket. \\
\hline Efikasi Diri & 26,800 & 0,913 & Normal \\
Perilaku Mencontek & 27,723 & 0,929 & Normal \\
\hline
\end{tabular}

Uji linieritas bertujuan untuk mengetahui korelasi dari dua variabel yang benar-benar mempunyai hubungan linier atau tidak. Linier tidaknya suatu hubungan dapat dilihat dari hasil analisis uji linieritas. Hubungan kedua variabel dikatakan linier jika $\mathrm{p}>0,05$ sebaliknya jika $\mathrm{p}<$ 0,05 maka kedua variabel tersebut tidak linier. Hasil uji linieritas hubungan dapat dilihat pada Tabel 5. Data pada tabel 5 menunjukkan bahwa ada hubungan linier antara efikasi diri dengan perilaku mencontek pada siswa kelas X SMA Negeri 4 Yogyakarta.

Hasil analisis korelasi antara efikasi diri dengan perilaku mencontek dapat dilihat pada Tabel 6. Berdasarkan data pada Tabel 6, dapat disimpulkan bahwa ada hubungan yang signifikan antara kedua variabel. Semakin tinggi Nilai koefisien efikasi diri maka semakin rendah perilaku mencontek dan sebaliknya apabila Efikasi diri rendah maka perilaku mencontek tinggi.

\section{Tabel 5}

Uji Linieritas Hubungan Antara Efikasi Diri dengan Perilaku Mencontek

\begin{tabular}{cccc}
\hline Variabel & $\mathrm{F}$ & $P$ & Hasil \\
\hline $\begin{array}{c}\text { Efikasi Diri-Perilaku } \\
\text { Mencontek }\end{array}$ & 1,231 & 0,293 & Linier \\
\hline
\end{tabular}

Tabel 6

Hasil Uji Korelasi

\begin{tabular}{ccc}
\hline Variabel & $\mathrm{r}_{\mathrm{xy}}$ & $\mathrm{P}$ \\
\hline $\begin{array}{c}\text { Efikasi Diri (X) - Perilaku } \\
\text { Mencontek (Y) }\end{array}$ & $-0,462$ & 0,000 \\
\hline
\end{tabular}

Berdasarkan hasil analisis korelasi product moment, maka dapat diketahui bahwa koefisiensi korelasi sebesar -0,462 dengan $p$ yaitu 0,000. Hal ini menunjukkan bahwa nilai $p<0,05$, dan karena nilai $p<0,05$ maka dari hasil korelasi dapat dikatakan signifikan. Dengan demikian maka hipotesis nihil (Ho) yang berbunyi “Tidak ada hubungan antara efikasi diri dengan perilaku mencontek pada siswa kelas X SMA Negeri 4
Yogyakarta” ditolak, sedangkan hipotesis alternatif (Ha) yang berbunyi "ada hubungan negatif antara efikasi diri dengan perilaku mencontek pada siswa kelas X SMA Negeri 4 Yogyakarta” teruji kebenarannya. Dari hasil analisis korelasi product moment yang menunjukkan bahwa $p<0,05$.

Nilai koefisien determinasi $\left(\mathrm{R}^{2}\right)$ merupakan kuadrat dari koefisien korelasi. Berdasarkan hasil perhitungan diperoleh nilai koefisien determinasi sebesar 0,213. Hal ini menunjukkan besarnya variasi perilaku mencontek yang dapat diterangkan oleh variabel efikasi diri sebesar $21,3 \%$ dan sisanya $78,7 \%$ dari perilaku mencontek disebabkan oleh variabel lain di luar efikasi diri seperti prokrastinasi, tekanan dari teman sebaya, dan tekanan dari orang tua.

Berdasarkan hasil analisis maka dapat disimpulkan analisis uji hipotesis penelitian adalah ada hubungan negatif antara efikasi diri dengan perilaku mencontek pada siswa kelas $\mathrm{X}$ SMA Negeri 4 Yogyakarta. Semakin tinggi efikasi diri siswa maka semakin rendah perilaku mencontek dan sebaliknya apabila efikasi diri siswa rendah maka perilaku mencontek tinggi. Hasil penelitian menunjukkan bahwa siswa kelas X SMA Negeri 4 Yogyakarta mempunyai efikasi diri dalam kategori sedang.

Siswa dengan efikasi diri tinggi memiliki pandangan positif terhadap setiap kegagalan dan menerima kekurangan yang dimiliki apa adanya, lebih aktif, dapat mengambil pelajaran dari masa lalu, mampu merencanakan tujuan dan membuat rencana kerja, lebih kreatif menyelesaikan masalah sehingga tidak membuat stres serta selalu berusaha lebih keras untuk mendapat prestasi belajar yang maksimal. Siswa dengan efikasi diri yang rendah adalah siswa yang memandang negatif terhadap dirinya maupun masyarakat, merasa tidak punya teman dan seolah-olah dirinya ditolak oleh lingkungan serta merasa kurang mampu untuk bersosialisasi dengan siswa lain, pasif dan sulit menyelesaikan tugas, tidak berusaha mengatasi masalah, tidak mampu belajar dari masa lalu, selalu merasa cemas, sering stress dan terkadang depresi.

Hasil penelitian juga menunjukkan bahwa siswa kelas X SMA Negeri 4 Yogyakarta mempunyai perilaku mencontek dalam kategori rendah. Siswa yang memiliki efikasi diri yang tinggi akan kemampuan akademik menunjukkan 
perilaku mencontek yang rendah daripada siswa yang memiliki tingkat efikasi diri yang rendah. Hal ini mempunyai arti bahwa siswa yang mempunyai tingkat efikasi tinggi cenderung untuk mempunyai perilaku mencontek yang rendah daripada siswa yang mempunyai efikasi rendah.

\section{Simpulan}

Berdasarkan hasil penelitian dan pembahasan yang telah diuraikan pada bab sebelumnya, maka pada penelitian ini dapat disimpulkan bahwa ada hubungan negatif antara efikasi diri dengan perilaku mencontek pada siswa kelas X SMA Negeri 4 Yogyakarta. Hasil penelitian ini semakin tinggi efikasi diri maka semakin rendah perilaku mencontek dan sebaliknya apabila efikasi diri rendah maka perilaku mencontek tinggi. Efikasi diri terhadap perilaku mencontek pada siswa kelas X SMA Negeri 4 Yogyakarta berperan sebesar $21,3 \%$ dan sisanya $78,7 \%$ perilaku mencontek disebabkan oleh variabel lain di luar efikasi diri seperti prokrastinasi, tekanan dari teman sebaya, dan tekanan dari orang tua. Hasil penelitian ini dapat dijadikan sebagai acuan dasar pengembangan program layanan bimbingan dan konseling untuk membantu siswa mengembangkan efikasi diri dalam meminimalisasikan perilaku mencontek.

\section{Referensi}

Alwisol. (2009). Psikologi Kepribadian. Malang: Umum Press.

Feist, J \& G, J, Feist. (2010). Teori Kepribadian: Theories of personality. Jakarta: Salemba Humanika.

Ghufron, M. Nur\& Rini Risnawita S. (2010). Teori-teori Psikologi. Yogyakarta: ArRuzz Media.

Hamdani, Rusydan Ubaidi. (2014). Mencontek...? Yuk!! Hmm..., Nggak Ah!!. Jakarta: Transmedia.

Hartanto, Dody. (2012). Bimbingan dan Konseling Mencontek: Mengungkap Akar Masalah dan Solusinya. Jakarta: Indeks.
Jannah, EMA Uzlifatul. (Sept 2013). Hubungan antara Self-Efficacydan Kecerdasan Emosional dengan Kemandirian pada Remaja.Persona, Jurnal Psikologi Indonesia Vol. 2, No. 2, Hlm. 278-287.

Komalasari, Gantina, dkk. (2011). Asesmen Teknik Nontes dalam Perspektif Bk Komprehensif. Jakarta: Indeks.

Kushartanti, Anugrahening (Nov 2009). Perilaku Mencontek Ditinjau Dari Kepercayaan Diri. Indigenous, Jurnal Ilmiah Berkala Psikologi Vol. 11, No. 2. Hlm. 38-46.

Nelson-Jones, Richard. (2011). Teori dan Praktik Konseling dan Terapi.Yogyakarta: Pustaka Pelajar.

Peraturan Menteri Pendidikan Nasional Nomor 35 Tahun 2010 Tentang Petunjuk Teknis Ketentuan Pelaksanaan Jabatan Fungsional dan Angka Kredit.

Prayitno \& Erman Amti. (2013). Dasar-Dasar Bimbingan Dan Konseling. Jakarta: Rineka Cipta.

Santoso, Budi. (2002). Perilaku Mencontek Siswa Sekolah Menengah Umum Dalam Ujian Dan Peran Guru Pembimbing.Tesis tidak diterbitkan. Padang: Universitas Negeri Padang.

Sari, Intan (2013). Locus of Controldan Perilaku Mencontekserta Implikasinya terhadap Bimbingan dan Konseling.Jurnal Ilmiah Konseling hlm. 267-272

Suherman, Uman. (2007). Manajemen Bimbingan dan Konseling. Jakarta: Madani.

Sutirna. (2013). Bimbingan dan Konseling: Pendidikan Formal, Non-formal dan Informal. Yogyakarta: Andi Offset.

Undang-Undang Sistem Pendidikan Nasional Nomor 20 Tahun 2003 pasal 3.

Widaryati, Sri. 2013. Efektivitas Pengaruh Konseling Kelompok terhadap Efikasi Diri Siswa SMA. PSIKOPEDAGOGIA Jurnal Bimbingan dan Konseling, 2(2): 25-31.

Yusuf, Syamsu. (2009). Program Bimbingan \& Konseling di Sekolah. Bandung: Rizqi Press.

Yusuf, Syamsu \& Juntika Nurihsan. (2007). Teori Kepribadian. Bandung: PT Remaja Rosdakarya. 